\section{PENGARUH BRAND AWARENESS, BRAND CHARACTERISTIC, DAN EMOTIONAL BRANDING TERHADAP KEPUTUSAN PEMBELIAN}

\author{
Farah Muthiah \& Budi Setiawan \\ Program Studi Pemasaran, Institut Bisnis dan Informatika Kesatuan \\ Bogor, Indonesia \\ Email :lemlit@stiekesatuan.ac.id
}

\title{
ABSTRACT
}

The research includes the type of survey research whose information is collected through questionnaires from respondents. The population of the study is the consumers who make purchasing decisions on beauty products Wardah. The sample of research is 100 respondents. Data collection techniques using questionnaires tested the validity and reliability. Data analysis techniques used to answer the hypothesis of research is multiple linear regression.

The result of this research shows that Brand Awareness has negative and insignificant effect on Wardah Beauty Decision, Brand Characteristic has a positive and significant influence on Purchasing Decision of Wardah beauty product, Emotional Branding has a positive and significant influence on Purchasing Decision of Wardah, Brand Awareness, Brand Characteristic, and Emotional Branding together have a positive and significant influence on Purchase Decision Wardah beauty products On STIE Kesatuan Bogor Students.

Key Words : Brand Awareness, Brand Characteristic, Emotional Branding and Purchase Decision

\section{PENDAHULUAN}

Pembelian suatu produk bukan lagi untuk memenuhi kebutuhan, melainkan karena memuaskan keinginan, karenanya keputusan pembelian konsumen merupakan hal yang sangat penting bagi kemajuan perusahaan. Semakin besar volume konsumen membeli suatu produk atau jasa pada suatu perusahaan, maka akan semakin besar peluang perusahaan untuk mendapatkan profit. Keputusan pembelian bukan hanya menghasilkan profit bagi suatu perusahaan, namun semakin banyak konsumen membeli maka produk akan semakin dikenal oleh masyarakat luas. Agar konsumen membeli produk yang dihasilkan, perusahaan dapat melakukan beberapa cara misalnya dengan memberikan kualitas yang terbaik pada produknya.

Kosmetik Wardah diciptakan pertama kali oleh ibu Nurhayati Subakat pada tahun 1995. Segmen Wardah pertama kali diarahkan bagi para muslimah dengan mengusung produk halal dan aman. Saat ini konsumennya tidak hanya kaum muslim tetapi juga non muslim, remaja dan dewasa menggunakan produk Wardah. Produk yang saat ini baru berusia 20 tahun, sudah menduduki peringkat yang memuaskan dalam penjualannya selama 3 tahun terakhir ini. Dengan mengusung tema "inspiring beauty" dan filosofi produk yaitu "earth, love, life" diharapkan produk Wardah mampu menginspriasi wanita Indonesia dalam menemukan keindahan diri dengan menggunakan produk yang halal dan aman dan dengan kecantikan dan keindahan tersebut nantinya akan mampu memberikan dampak positif pada lingkungan sekitar (http://www.dream.co.id/).

Kemampuan Wardah dalam memberikan manfaat secara nyata, menjadikan Wardah menempati urutan pertama sebagai brand yang diminati konsumen terhadap

Pengaruh Brand Awareness, Brand

Characteristic, dan Emotional

Branding terhadap Keputusan Pembelian

\section{9}

Submitted: MEI 2019

Accepted: OKTOBER 2019 
beberapa produknya. Meskipun demikian Wardah harus tetap memperluas penjualan dan produknya harus tetap berinovasi, agar produk Wardah semakin dikenal oleh masyarakat, meskipun semakin banyak pesaing brand dari luar negeri yang terus berkembang dan diminati oleh masyarakat di Indonesia. Dengan demikian Wardah harus tetap survive dengan pesaing lainnya, baik yang berasal dari luar negeri maupun dalam negeri.

\section{TINJAUAN PUSTAKA}

\section{Keputusan Pembelian}

Proses pengambilan keputusan yang rumit sering harus melibatkan beberapa keputusan. Suatu keputusan (decision) melibatkan pilihan diantara dua atau lebih alternatif tindakan (atau perilaku). Keputusan mensyaratkan pilihan diantara beberapa perilaku yang berbeda (Nugroho, 2013).

Menurut Kotler dan Amstrong (2008): "Keputusan pembelian adalah tahap proses keputusan dimana konsumen secara aktual melakukan pembelian produk".

\section{Brand Awareness}

Tjiptono, (2011:97) mengemukan pendapatnya bahwa Brand awareness merupakan kemampuan konsumen untuk mengenali atau mengingat bahwa sebuah merek merupakan anggota dari kategori produk tertentu.

Pendapat Keller yang dikutip oleh Radder dan Huang, (2008:79) mengatakan bahwa kesadaran merek diciptakan dan ditingkatkan dengan cara meningkatkan keakraban merek melalui paparan berulang sehingga konsumen merasa mengenal merek tersebut.

Sedangkan Rangkuti (2002:39), mengemukakan pendapatnya bahwa tingkat kesadaran merek pada benak konsumen berbeda-beda pada setiap tahapannya, yaitu: 1 . Unaware of brand (tidak menyadari merek) 2. Brand recognition (pengenalan merek) 3 . Brand recall (pengingatan kembali terhadap merek) 4. Top of mind (puncak pikiran).

\section{Brand Characteristic}

Lau dan Lee, (1999), mengemukakan pendapatnya bahwa Karakteristik merek memainkan peran yang vital dalam menentukan apakah pelanggan memutuskan untuk percaya pada suatu merek. Berdasarkan atas penelitian kepercayaan interpersonal, individu-individu yang dipercaya didasarkan pada reputation, predictability dan competence dari individu tersebut.

Dalam konteks hubungan pelanggan merek, kepercayaan pelanggan terbangun atas dasar reputasi merek, prediktabilitas merek, dan kompetensi merek.

\section{Emotional Branding}

Emotional branding adalah saluran dimana orang secara tidak sadar berhubungan dengan perusahaan dan dengan produk dari perusahaan tersebut dalam suatu metode yang mengagumkan secara emosional. Perusahaan yang mampu menciptakan kedekatan secara emosional kepada para pelanggannya akan mendapatkan kepercayaan dan loyalitas dari pelanggannya untuk terus berlangganan terhadap produk perusahaan tersebut. Marc Gobe (2005). 


\section{METODE PENELITIAN}

Penelitian ini menggunakan metode kuantitatif, dengan tujuan untuk mengetahui sejauh mana pengaruh brand awareness, brand characteristic, dan emotional branding terhadap keputusan pembelian (Studi kasus produk kecantikan Wardah pada mahasiswi STIE Kesatuan Bogor). Melalui metode penelitian ini akan dilakukan komparasi antara teori dan praktek/fakta di lapangan, sehingga dapat diperkirakan besarnya pengaruh secara kuantitatif dari perubahan satu atau beberapa kejadian lainnya, dengan menggunakan alat analisis statistik.

Metode analisis data yang digunakan dalam penelitian ini adalah analisis regresi berganda, yaitu dengan menghitung analisis korelasi, koefisien determinasi $\left(\mathrm{R}^{2}\right)$, dan uji hipotesis statistik yaitu uji $\mathrm{t}$ (parsial) dan uji f (simultan).

\section{HASIL DAN PEMBAHASAN}

\section{A. Analisis Regresi Berganda}

Tabel 1 .

Persamaan Regresi

\section{Coefficients $^{\mathrm{a}}$}

\begin{tabular}{llrrrrr}
\hline & \multicolumn{5}{c}{ Standardized } \\
Model & \multicolumn{2}{c}{ Unstandardized Coefficients } & \multicolumn{2}{c}{ Coefficients } \\
\cline { 2 - 5 } & \multicolumn{1}{c}{ B } & Std. Error & Beta & \multicolumn{1}{c}{ T } & Sig. \\
\hline (Constant) & 8,412 & 2,380 & & 3,534 &, 001 \\
& Brand Awareness &,- 031 &, 103 &,- 031 &,- 299 &, 766 \\
Brand Characteristic &, 195 &, 098 &, 194 & 1,996 &, 049 \\
Emotinal Branding &, 483 &, 115 &, 464 & 4,216 &, 000 \\
\hline
\end{tabular}

a. Dependent Variable: Purchasing Decision

Data diolah dengan SPSS, 2018

Berdasarkan tabel diatas, dapat ditentukan persamaan regresi berganda untuk penelitian ini sebagai berikut:

$$
\widehat{Y}=8,412+\left(-0,031 x_{1}\right)+0,195 x_{2}+0,483 x_{3}+\text { error }
$$

Berdasarkan persamaan regresi di atas, jika:

a. $\mathrm{X}_{1}=\mathrm{X}_{2}=\mathrm{X}_{3}=0$, maka $\mathrm{Y}$ nilainya sebesar 8,412

b. Jika $X_{1}$ naik sebesar 1 (satu) satuan maka Y akan turun sebesar 0,031 jika variabel lain dianggap konstan

c. Jika $X_{2}$ naik sebesar 1 (satu) satuan maka $Y$ akan naik sebesar 0,195 jika variabel lain dianggap konstan

d. Jika $\mathrm{X}_{3}$ naik sebesar 1 (satu) satuan maka $\mathrm{Y}$ akan naik sebesar 0,483 jika variabel lain dianggap konstan

\section{B. Korelasi Antar Variabel}

Tabel 2

Korelasi Antar Variabel 


\begin{tabular}{|c|c|c|c|c|c|}
\hline \multicolumn{6}{|c|}{ Correlations } \\
\hline & & $\begin{array}{c}\text { Brand } \\
\text { Awareness }\end{array}$ & $\begin{array}{c}\text { Brand } \\
\text { Characteristic }\end{array}$ & $\begin{array}{c}\text { Emotional } \\
\text { Branding }\end{array}$ & $\begin{array}{l}\text { Keputusan } \\
\text { Pembelian }\end{array}$ \\
\hline \multirow[t]{3}{*}{ Brand Awareness } & Pearson Correlation & 1 &, $357^{* *}$ &, $568^{* *}$ &, $302^{* * *}$ \\
\hline & Sig. (2-tailed) & &, 000 & 000 & ,002 \\
\hline & $N$ & 100 & 100 & 100 & 100 \\
\hline \multirow{3}{*}{$\begin{array}{l}\text { Brand } \\
\text { Characteristic }\end{array}$} & Pearson Correlation &, $357^{* *}$ & 1 &, $490^{* * *}$ &, $410^{* *}$ \\
\hline & Sig. (2-tailed) &, 000 & & 000 & 000 \\
\hline & $N$ & 100 & 100 & 100 & 100 \\
\hline \multirow{3}{*}{$\begin{array}{l}\text { Emotional } \\
\text { Branding }\end{array}$} & Pearson Correlation &, $568^{* *}$ &, $490^{* *}$ & 1 &, $542^{* *}$ \\
\hline & Sig. (2-tailed) & ,000 &, 000 & & ,000 \\
\hline & $N$ & 100 & 100 & 100 & 100 \\
\hline \multirow{3}{*}{$\begin{array}{l}\text { Keputusan } \\
\text { Pembelian }\end{array}$} & Pearson Correlation & $302^{* * *}$ & $410^{* * *}$ &, $542^{* *}$ & 1 \\
\hline & Sig. (2-tailed) & ,002 &, 000 & , 000 & \\
\hline & $N$ & 100 & 100 & 100 & 100 \\
\hline
\end{tabular}

Data diolah dengan SPSS, 2018

Hasil Uji Korelasi

1) Berdasarkan tabel diatas menunjukkan bahwa variabel Brand Awareness berkorelasi positif sebesar 0,357 terhadap variabel Brand Characteristic, dan dapat disimpulkan bahwa kedua variabel tersebut memiliki korelasi yang signifikan antara variabel yang dihubungkan.

2) Berdasarkan tabel diatas menunjukkan bahwa variabel Brand Awareness berkorelasi positif sebesar 0,568 terhadap variabel Emotional Branding, dan dapat disimpulkan bahwa kedua variabel tersebut memiliki korelasi yang signifikan antara variabel yang dihubungkan.

3) Berdasarkan tabel diatas menunjukkan bahwa variabel Brand Awareness berkorelasi positif sebesar 0,302 terhadap variabel Purchasing Decision, dan dapat disimpulkan bahwa kedua variabel tersebut memiliki korelasi yang signifikan antara variabel yang dihubungkan.

4) Berdasarkan tabel diatas menunjukkan bahwa variabel Brand Characteristic berkorelasi positif sebesar 0,490 terhadap variabel Emotional Branding, dan dapat disimpulkan bahwa kedua variabel tersebut memiliki korelasi yang signifikan antara variabel yang dihubungkan.

5) Berdasarkan tabel diatas menunjukkan bahwa variabel Brand Characteristic berkorelasi positif sebesar 0,410 terhadap Purchasing Decision, dan dapat disimpulkan bahwa kedua variabel tersebut memiliki korelasi yang signifikan antara variabel yang dihubungkan.

6) Berdasarkan tabel diatas menunjukkan bahwa variabel Emotional Branding berkorelasi positif sebesar 0,542 terhadap variabel Purchasing Decision, dan dapat disimpulkan bahwa kedua variabel tersebut memiliki korelasi yang signifikan antara variabel yang dihubungkan.

\section{Koefisien Korelasi dan Koefisien Determinasi}




\begin{tabular}{cc}
\hline $\mathrm{R}$ & $\mathrm{R}$ Square \\
\hline 0,567 & 0,322 \\
\hline
\end{tabular}

Berdasarkan tabel diatas dan hasil output model summary dapat dijelaskan bahwa hubungan atau korelasi berganda pada seluruh variabel (Brand Awareness, Brand Characteristic, Emotional Branding, dan Keputusan Pembelian), memiliki kekuatan hubungan yang rendah. Hal ini dilihat berdasarkan nilai koefisien korelasi berganda sebesar 0,567. Perolehan nilai koefisien determinasi r-square sebesar 0,322 dapat dijelaskan bahwa variabel Brand Awareness, Brand Characteristic, Emotional Branding, dan Keputusan Pembelian mampu mempengaruhi atau menjelaskan keragaman (variabilitas) nilai dari Keputusan Pembelian sebesar 32,2\%, sedangkan sisanya sebesar (100\% - 32,2\% ) 67,8\% dipengaruhi variabel lain di luar model atau dijelaskan oleh variabel lain yang tidak diteliti.

\section{Uji Hipotesis Statistik}

\section{Uji t (Uji Parsial)}

a) Hubungan antara Brand Awareness (X1) terhadap Keputusan Pembelian (Y)

\begin{tabular}{|l|l|}
\hline Hipotesis penelitian 1 & $\begin{array}{l}\text { Brand Awareness mempunyai pengaruh positif } \\
\text { dan signifikan terhadap Keputusan Pembelian }\end{array}$ \\
\hline $\mathrm{H}_{0}: \beta 1=0$ & $\begin{array}{l}\text { Brand Awareness tidak mempunyai pengaruh } \\
\text { dengan Keputusan Pembelian }\end{array}$ \\
\hline $\mathrm{H}_{1}: \beta 1 \neq 0$ & $\begin{array}{l}\text { Brand Awareness mempunyai pengaruh dengan } \\
\text { Keputusan Pembelian }\end{array}$ \\
\hline
\end{tabular}

Berdasarkan tabel diatas hubungan antara Brand Awareness $\left(\mathrm{X}_{1}\right)$ dengan Keputusan Pembelian (Y) diperoleh t hitung sebesar -0,299 dan lebih kecil dari t-tabel ( $\mathrm{df}$ $=\mathrm{n}-\mathrm{k}-1$ atau $\mathrm{df}=100-3-1=96 ; \alpha=5 \%)=1,66$ dan nilai sig $0,766>0,05 ; \mathrm{H} 0$ diterima dan $\mathrm{H}_{1}$ ditolak. Simpulan hipotesis penelitian pertama ditolak, berarti ada pengaruh yang negatif dan tidak signifikan antara Brand Awareness $\left(\mathrm{X}_{1}\right)$ dengan Keputusan Pembelian (Y).

b) Hubungan antara Brand Characteristic $\left(\mathrm{X}_{2}\right)$ terhadap Keputusan Pembelian (Y)

\begin{tabular}{|l|l|}
\hline Hipotesis penelitian 2 & $\begin{array}{l}\text { Brand Characteristic mempunyai pengaruh } \\
\text { positif dan signifikan terhadap Keputusan } \\
\text { Pembelian }\end{array}$ \\
\hline $\mathrm{H}_{0}: \beta 2=0$ & $\begin{array}{l}\text { Brand Characteristic tidak mempunyai } \\
\text { pengaruh dengan Keputusan Pembelian }\end{array}$ \\
\hline $\mathrm{H}_{2}: \beta 2 \neq 0$ & $\begin{array}{l}\text { Brand Characteristic mempunyai pengaruh } \\
\text { dengan Keputusan Pembelian }\end{array}$ \\
\hline
\end{tabular}

Berdasarkan tabel diatas hubungan antara Brand Characteristic $\left(\mathrm{X}_{2}\right)$ dengan Keputusan Pembelian (Y) diperoleh t hitung sebesar 1,996 dan lebih besar dari t-tabel $(\mathrm{df}=\mathrm{n}-\mathrm{k}-1$ atau $\mathrm{df}=100-3-1=96 ; \alpha=5 \%)=1,66$ dan nilai sig $0,049<0,05 ; \mathrm{H}_{0}$ ditolak dan $\mathrm{H}_{2}$ diterima. Simpulan hipotesis penelitian kedua diterima, berarti ada pengaruh yang positif dan signifikan antara Brand Characteristic $\left(\mathrm{X}_{2}\right)$ dengan Keputusan Pembelian (Y).

c) Hubungan antara Emotional Branding $\left(\mathrm{X}_{3}\right)$ terhadap Purchasing Decision $(\mathrm{Y})$ 


\begin{tabular}{|l|l|}
\hline Hipotesis penelitian 3 & $\begin{array}{l}\text { Emotional Branding mempunyai pengaruh } \\
\text { positif dan signifikan terhadap Keputusan } \\
\text { Pembelian }\end{array}$ \\
\hline $\mathrm{H}_{0}: \beta 3=0$ & $\begin{array}{l}\text { Emotional Branding tidak mempunyai } \\
\text { pengaruh dengan Keputusan Pembelian }\end{array}$ \\
\hline $\mathrm{H}_{3}: \beta 3 \neq 0$ & $\begin{array}{l}\text { Emotional Branding mempunyai pengaruh } \\
\text { dengan Keputusan Pembelian }\end{array}$ \\
\hline
\end{tabular}

Berdasarkan tabel diatas hubungan antara Emotional Branding $\left(\mathrm{X}_{3}\right)$ dengan Keputusan Pembelian (Y) diperoleh t hitung sebesar 4,216 dan lebih besar dari t-tabel $(\mathrm{df}=\mathrm{n}-\mathrm{k}-1$ atau $\mathrm{df}=100-3-1=96 ; \alpha=5 \%)=1,66$ dan nilai sig $0,000<0,05 ; \mathrm{H} 0$ ditolak dan $\mathrm{H}_{3}$ diterima. Simpulan hipotesis penelitian ketiga diterima, berarti ada pengaruh yang positif dan signifikan antara Emotional Branding $\left(\mathrm{X}_{3}\right)$ dengan Keputusan Pembelian (Y).

\section{Uji F (Uji Simultan)}

Tabel 4

Uji F (Simultan)

\begin{tabular}{lrrrr}
\hline & Df & Mean Square & F & Sig. \\
\hline \multicolumn{1}{c}{ Regression } & 3 & 94,050 & 15,182 &, $000^{\mathrm{b}}$ \\
$\quad$ Residual & 96 & 6,195 & & \\
\multicolumn{1}{c}{ Total } & 99 & & & \\
\hline a. Dependent Variable: & & & & \\
Keputusan Pembelian \\
b. Predictors: (Constant), Emotional Branding, Brand Characteristic, Brand Awareness
\end{tabular}

\begin{tabular}{|l|l|}
\hline Hipotesis penelitian 4 & $\begin{array}{l}\text { Brand Awareness, Brand Characteristic dan } \\
\text { Emotional Branding secara bersama-sama } \\
\text { mempunyai pengaruh positif dan signifikan } \\
\text { terhadap Keputusan Pembelian }\end{array}$ \\
\hline $\mathrm{H}_{0}: \beta 1=\beta 2=\beta 3=$ & $\begin{array}{l}\text { Brand Awareness, Brand Characteristic dan } \\
\text { Emotional Branding secara bersama-sama tidak } \\
\text { mempunyai pengaruh dengan Keputusan } \\
\text { Pembelian }\end{array}$ \\
\hline $\mathrm{H}_{4}: \beta 1 \neq \beta 2 \neq \beta 3 \neq 0$ & $\begin{array}{l}\text { Brand Awareness, Brand Characteristic dan } \\
\text { Emotional Branding secara bersama-sama } \\
\text { mempunyai pengaruh dengan Keputusan } \\
\text { Pembelian }\end{array}$ \\
\hline
\end{tabular}

Berdasarkan tabel diatas hubungan antara Brand Awareness, Brand Characteristic dan Emotional Branding dengan Keputusan Pembelian diperoleh f-hitung 15,182 dan lebih besar dari f-tabel $(\mathrm{df1}=3, \mathrm{df} 2=97, \alpha=5 \%)=2,70$; dan didukung oleh nilai signifikansi sebesar 0,000 dan lebih kecil dari $(\alpha=5 \%)=0,05$ dengan demikian $\mathrm{H}_{0}$ ditolak dan $\mathrm{H}_{1}$ diterima, Brand Awareness, Brand Characteristic dan Emotional Branding secara bersama-sama mempunyai pengaruh terhadap Keputusan Pembelian, maka hipotesis keempat diterima.

\section{E. Pembahasan}

Berdasarkan hasil kuesioner dan pengolahan data kuesioner menggunakan program SPSS yang telah dilakukan, maka pembahasan terhadap hipotesis penelitian adalah sebagai berikut: 


\section{A. Pengaruh Brand Awareness (X), Brand Characteristic ( $\left.\mathbf{X}_{2}\right)$ dan Emotional Branding $\left(\mathrm{X}_{3}\right)$ secara bersama-sama terhadap Keputusan Pembelian (Y)}

Penelitian ini didasarkan pada hasil uji statistik terhadap hipotesis keempat yang berbunyi terdapat hubungan antara pengaruh Brand Awareness, Brand Characteristic dan Emotional Branding dengan Keputusan Pembelian dapat diterima, hal ini ditunjukan dengan nilai f-hitung sebesar 15,182 yang hasilnya lebih besar dibandingkan f-tabel yaitu sebesar 2,70 dan didukung oleh nilai signifikansi 0,000 lebih kecil dibandingkan 0,05, dimana variabel Brand Awareness, Brand Characteristic dan Emotional Branding secara bersama-sama berpengaruh positif dan signifikan terhadap Keputusan Pembelian maka Hipotesis 4 diterima.

\section{B. Pengaruh Brand Awareness (X1) terhadap Keputusan Pembelian (Y)}

Penelitian ini didasarkan pada hasil uji statistik diatas, hipotesis pertama yang berbunyi terdapat hubungan antara pengaruh Brand Awareness terhadap Keputusan Pembelian tidak dapat diterima, hal ini ditunjukan dengan nilai t-hitung sebesar -0,299 yang dimana lebih kecil dibandingkan t-tabel 1,66 dan nilai signifikansi 0,766 lebih besar dibandingkan 0,05 yang dimana variabel tersebut berpengaruh negatif dan tidak signifikan terhadap Keputusan Pembelian maka Hipotesis 1 ditolak. Hasil temuan ini bertolak belakang dengan hasil penelitian yang dilakukan oleh Dimas Surya Wijaya (2011), dimana hasilnya adalah brand awareness berpengaruh signifikan terhadap keputusan pembelian.

Namun, peneliti melakukan wawancara kepada 4 (empat) responden dari mahasiswi STIE Kesatuan Bogor untuk menguatkan hasil penelitian ini. Keempat responden menjawab dan dapat disimpulkan bahwa pada masa modern seperti ini banyaknya kosmetik luar negeri yang hadir di Indonesia yang memiliki kualitas dan harga yang masih dapat dijangkau, kemudian masyarakat lebih memilih merek luar negeri karena memiliki perasaan bangga tersendiri karena masyarakat di Indonesia cenderung memiliki sifat gengsi, kemudian di era digital seperti sekarang para beauty influencer cenderung memakai produk dari luar negeri untuk di review, hal ini sangat mempengaruhi pikiran masyarakat dalam menilai suatu produk kecantikan. Dengan demikian dapat disimpulkan bahwa masyarakat remaja-dewasa lebih aware pada kosmetik luar negeri dibanding kosmetik lokal.

\section{Pengaruh Brand Characteristic $\left(\mathbf{X}_{2}\right)$ terhadap Keputusan Pembelian (Y)}

Penelitian ini didasarkan pada hasil uji statistik, dimana hipotesis pertama menyatakan bahwa terdapat hubungan antara pengaruh Brand Characteristic terhadap Keputusan Pembelian dapat diterima, hal ini ditunjukan dengan nilai t-hitung sebesar 1,996 lebih besar bila dibandingkan dengan t-tabel 1,66. Sedangkan nilai signifikansi 0,049 lebih kecil dibandingkan 0,05 dimana variabel tersebut berpengaruh positif dan signifikan terhadap Keputusan Pembelian, sehiungga Hipotesis 2 diterima. Hasil temuan ini sejalan dengan teori Lau dan Lee dalam Rully Tjahyadi (2006) bahwa karakteristik merek mempunyai peran yang sangat penting dalam menentukan pengambilan keputusan konsumen untuk mempercayai suatu merek. Hal ini disebabkan oleh konsumen melakukan penilaian sebelum membeli.

\section{Pengaruh Emotional Branding $\left(\mathrm{X}_{3}\right)$ terhadap Keputusan Pembelian (Y)}

Penelitian ini didasarkan pada hasil uji statistik, dimana hipotesis ketiga menyatakan terdapat hubungan antara pengaruh Emotional Branding terhadap 
Keputusan Pembelian, dapat diterima. Hal ini ditunjukkan dengan nilai t-hitung sebesar 4,216 lebih besar dibandingkan t-tabel 1,66. Sedangkan nilai signifikansi 0,000 lebih kecil dibandingkan 0,05 dimana variabel tersebut berpengaruh positif dan signifikan terhadap Keputusan Pembelian, sehingga Hipotesis 3 diterima. Hasil temuan ini sejalan dengan hasil penelitian Augtinus Adi Andryanto (2009), bahwa emotional branding memiliki hubungan yang positif, kuat dan signifikan terhadap keputusan pembelian.

\section{SIMPULAN}

Berdasarkan hasil pembahasan yang ada, maka dapat disimpulkan sebagai berikut:

1. Brand Awareness $\left(\mathrm{X}_{1}\right)$, Brand Characteristic $\left(\mathrm{X}_{2}\right)$, Emotional Branding $\left(\mathrm{X}_{3}\right)$ mempunyai pengaruh terhadap Keputusan Pembelian (Y). Hasil pengujian statistik menunjukan bahwa Brand Awareness, Brand Characteristic, Emotional Branding berpengaruh positif dan signifikan terhadap Keputusan Pembelian secara simultan. Artinya, ketiga variabel independen disimpulkan bahwa hipotesis pertama, kedua dan ketiga yang menyatakan dugaan adanya pengaruh terhadap dependen dapat diterima.

2. Brand Awareness $\left(\mathrm{X}_{1}\right)$ tidak mempunyai pengaruh terhadap Keputusan Pembelian (Y). Hasil pengujian statistik menunjukan bahwa brand awareness berpengaruh negatif dan tidak signifikan terhadap keputusan pembelian. Artinya, terjadinya keputusan pembelian pada kosmetik Wardah di STIE Kesatuan Bogor tidak dapat dijelaskan oleh kesadaran merek yang dirasakan oleh konsumen. Pengaruhnya negatif dan tidak signifikan antara brand awareness dan keputusan pembelian dikarenakan masyarakat cenderung memilih brand dari luar negeri karena adanya beberapa faktor salah satunya perasaan gengsi yang dimiliki oleh konsumen.

3. Brand Characteristic $\left(\mathrm{X}_{2}\right)$ mempunyai pengaruh terhadap Keputusan Pembelian (Y). Hasil pengujian statistik menunjukan bahwa brand characteristic berpengaruh positif dan signifikan terhadap keputusan pembelian. Artinya, terjadinya keputusan pembelian pada kosmetik Wardah di STIE Kesatuan Bogor dapat dijelaskan oleh brand characteristic yang dirasakan oleh konsumen. Hal ini berarti semakin tinggi brand characteristic maka akan semakin tinggi keputusan pembelian.

4. Emotional Branding $\left(\mathrm{X}_{3}\right)$ mempunyai pengaruh terhadap Keputusan Pembelian (Y). Hasil pengujian statistik menunjukan bahwa emotional branding berpengaruh positif dan siginifikan terhadap keputusan pembelian. Artinya, terjadinya keputusan pembelian pada kosmetik Wardah di STIE Kesatuan Bogor dapat dijelaskan oleh emotional branding yang dirasakan oleh konsumen. Hal ini berarti semakin tinggi emotional branding maka akan semakin tinggi keputusan pembelian.

\section{DAFTAR PUSTAKA}

Fandy, Tjiptono. 2011. Service Management Mewujudkan Layanan Prima. Edisi2. Yogyakarta : Andi.

Gobe, Marc. 2005. Emotional Branding: Paradigma Baru untuk Menghubungkan Merek dengan Pelanggan. Jakarta : Erlangga. 
Huang, Wei and Laetitia Radder. 2008. High Involvement and Low Involvement Products AComparison of Brand Awareness Among Student at A South African Univercity. South Africa.

Kotler, P., Amstrong, G. 2008. Prinsip-pronsip Pemasaran. Edisi 12. Jilid 1. Jakarta:Erlangga.

Lau, Geok Then and Lee, Sook Han. 1999. "Consumers Trust in a Brand and the Link to Brand Loyalty". Journal of Market Focused Management.

Nuhroho, J. Setiadi.2013. Perilaku Konsumen, Edisi Revisi. Jakarta : Kencana.

Rangkuti, Freddy (2002), Measuring Customer Satisfaction, Penerbit PT. Gramedia Pustaka Utama, Jakarta. 